\title{
NUP98/SETBP1 Fusion Protein
}

National Cancer Institute

\section{Source}

National Cancer Institute. NUP98/SETBP1 Fusion Protein. NCI Thesaurus. Code C99456.

A fusion protein encoded by the NUP98/SET BP1 gene. This protein is comprised of the $\mathrm{N}$-terminal nucleoporin GLFG repeat domains of the nuclear pore complex protein Nup98-Nup96 protein fused to the C-terminus of the SET-binding protein. 